\title{
Effect of Co-existent Bacteria on the Growth of Chattonella marina in Non-axenic Culture
}

\author{
Sukoso and Taizo Sakata \\ Microbiology Laboratory, Faculty of Fisheries, Kagoshima University, Shimoarata, \\ Kagoshima 890, Japan
}

(Received July 11, 1995)

\begin{abstract}
The laboratory stock culture of Chattonella marina harbors several bacterial strains and has been surviving in hundred times of transfer process. As predominant bacteria, Alteromonas, Flexibacter and Pseudomonas spp. were isolated from a non-axenic culture of C. marina. In the state of mixed cultures of an axenic algal strain with co-existent bacterial isolates, the living algal cells were maintained over 30 days after transferred to enrichment sea water (ESS) medium. On the other hand, algal cells began to decrease at 10 days and were not detected at 30 days at all in axenic cultures. On the addition of enrichment solution (ESP) into axenic cultures, algal cells were stimulated to grow even after reached maximum growth. When above $100 \mathrm{mg} / l$ of polypepton was added to non-axenic cultures, the algal cell counts decreased as the total bacterial counts increased. If the supernatant solutions of co-existent bacterial cultures incubated in nutrient rich media (ZE-CI) were added to algal axenic cultures, algal cells were completely killed in above $5 \%$ concentrations within 7 days incubation.
\end{abstract}

Key words: Chattonella marina, microalgae, co-existent bacteria, axenic culture, Alteromonas, Flexibacter

Microalgae and bacteria are numerically dominant organisms in aquatic ecosystems and they play important roles as primary producers and decomposers, respectively. Microalgae produce various organic substances photosynthetically and excrete a part of them, which is utilized by bacteria as carbon and energy sources. ${ }^{1-3)}$ On the other hand, the roles of bacteria are to stimulate or inhibit algal growth through the decomposition of organic compounds, endosymbiosis, and production of stimulative or inhibitory substances for algal cells. The relationship between microalgae and bacteria can occur temporarily or permanently, within or in the vicinity of algal cells. This relationship can be caused by physical support or chemical factors, or both. On the basis of nutritional necessity, the possible interactions between microalgae and bacteria can be recognized as competition, commensalism or parasitism. $\left.{ }^{4-6}\right)$

Many attempts to elucidate the relationship between microalgae and bacteria in aquatic environments have been done by various investigators. For examples, Riquelme et al.," reported that the growth of a marine diatom, Asterionella glacialis was strongly stimulated by a Psudomonas strain through some bacterial metabolites. Fukami et $a l^{8)}$ demonstrated that natural communities of bacteria give a stimulating or have an inhibitory effect on Skeletonema costatum and Gymnodinium nagasakiense, and cause the succession of these algal species. As cyanobacterial-bacterial association, Paerl and Galluccip) observed that Anabaena oscillarioides excrete products responsible for positive chemotaxis in pseudomonads.

Red tide by Chattonella marina happened in Kagoshima Bay in 1985 and algal strains were isolated by some workers. A strain of $C$. marina was given and has been maintained in our laboratory. The stock culture of $C$. marina strain harbors several species of bacteria as co-existent partners. A non-axenic culture of this algal strain has been found to maintain viable algal cells for a longer time than the axenic culture. This phenomenon is considered to be dependent on the actions of co-existent bacteria in the algal culture. The favorable effects of co-existent bacteria on the algal growth may be explained in terms of decomposition of toxic metabolites derived from algal cells or production of stimulative substances for algal growth by the bacteria.

In this paper, we attempted to clarify the effect of co-existent bacteria on the growth of red tide microalga, Chattonella marina isolated from Kagoshima Bay and maintained in the laboratory.

\section{Materials and Methods}

\section{Algal Culture}

We are indebted to Mr. T. Aramaki, Fisheries Station of Kagoshima Prefecture, for the Chattonella marina strain, who isolated it when red tide occurred in Kagoshima Bay in 1985 and the alga was cultured in $10 \mathrm{~m} /$ of modified Provasoli's enrichment sea water medium $(E S S)^{10)}$ under illumination $(7,000 \mathrm{~lx}$ in the light cycle of 12L: $12 \mathrm{D}, 23^{\circ} \mathrm{C}$ ). ESS medium consisted of $5 \mathrm{~m} l$ of $\mathrm{Na}_{2} \mathrm{SiO}_{3}$ solution $(1 \mathrm{mg} / l), 40 \mathrm{~m} l$ of Provasoli's enrichment solution (ESP) containing $\mathrm{NaNO}_{3} 350 \mathrm{mg}, \alpha-$ glycerophosphate $50 \mathrm{mg}$, Fe-EDTA $2.5 \mathrm{mg}$, vitamin $B_{12}$ $10 \mu \mathrm{g}$, biotin $5 \mu \mathrm{g}$, vitamin $\mathrm{B}_{1} 500 \mu \mathrm{g}$, tris-aminomethane $500 \mathrm{mg}$, PII metal solution $25 \mathrm{~m} l / l, 900 \mathrm{~m} l$ of filtered natural sea water, and $100 \mathrm{~m} l$ of distilled water $(\mathrm{pH} 7.8)$.

\section{Bacterial Strains}

The bacterial strains were isolated from a stock culture 
of $C$. marina by using the dilution and plating method. Bacterial colonies were picked up from an agar plate and purified on YES agar. YES agar medium was prepared by the addition of yeast extract (Nihon Seiyaku) $1 \mathrm{~g}$ and agar $15 \mathrm{~g}$ to $1,000 \mathrm{~m} l$ of ESS medium.

\section{Axenic Algal Culture}

An axenic algal strain was isolated from the original non-axenic stock culture by using the long tube technique. ${ }^{11)}$ By exploiting the positive-phototaxis of algal cells and antibiotics including streptomycin sulfate, kanamycin sulfate and penicillin $\mathrm{G}$ (each, $50 \mathrm{mg} / l$ ) in ESS medium, the algal cell isolation was carried out under illumination.

\section{Bacterial Colony Count}

Bacterial viable cells were detected by dilution spreadplate technique. Samples were transferred by pipette into a serial dilution solution in $3 / 4$ artificial sea water (Herbst's formula artificial sea water, ASW) and then $0.1 \mathrm{~m} l$ of the respective dilution solution was smeared on ZE-CI agar medium and incubated at $25^{\circ} \mathrm{C}$. ZE-CI medium contained polypepton (Nihon Seiyaku) $5 \mathrm{~g}$, yeast extract (Nihon Seiyaku) $1 \mathrm{~g}$ and ESS medium $1,000 \mathrm{~m} l$ as described in the previous paper. ${ }^{12)}$ The apparent colonies were counted after 6 days incubation at $25^{\circ} \mathrm{C}$.

\section{Algal Cell Count}

Algal cells in axenic or mixed cultures were counted by direct count method (Thoma cytometer chamber) under a light microscope. Algal motility was stopped by keeping algal cells that were placed on Thoma glass in petri-dish with acetic acid solution for $5 \mathrm{~min}$. Algal cell counts (log No./ $\mathrm{ml}$ ) were expressed as an average of 5 samples from an algal culture.

\section{Characterization of Bacterial Strains}

For the identification of co-existent bacterial strains isolated from algal non-axenic cultures, the basal characterization tests were carried out based on morphological characters (colony, cell form, gram stain and motility), biochemical reactions (pigmentation, catalase, oxidase and Hugh-Leifson test), and macromolecular degradations (casein, starch and DNA) according to general procedures. Bacterial genera were identified according to the identification scheme presented by Simidu. ${ }^{13)}$

\section{Growth of Algal Cells in Axenic and Mixed Cultures}

The growth of alga and co-existent bacteria were determined after transferring $0.5 \mathrm{~m} l$ of an non-axenic algal culture into $9.5 \mathrm{~m} l$ of ESS liquid medium and incubated at $23^{\circ} \mathrm{C}$ under illumination of $7,000 \mathrm{~lx}$ (12L:12D). On the other hand, mixed cultures of axenic algal cells and each bacterial isolate were conducted as follows; $0.5 \mathrm{ml}$ of bacterial dilution solution prepared from the rotating cultures in L-shape test tubes containing $10 \mathrm{~m} l$ of $\mathrm{ZE}-\mathrm{CI}$ medium and $0.5 \mathrm{~m} l$ of an axenic algal culture were transferred into $9.5 \mathrm{~m} / \mathrm{ESS}$ media in large test tubes.

\section{Effect of Enrichment Solution and Polypepton on Algal Growth \\ In order to examine the effect of enrichment solution (ESP) on axenic algal growth, $0.4 \mathrm{~m} /$ of ESP was added to algal cultures $(10 \mathrm{ml})$ after algal cells reached maximum number. The effect of polypepton on non-axenic culture of the alga was examined by adding polypepton at 50,75 , 100,150 , and $250 \mathrm{mg} / l$ concentrations into ESS medium $(10 \mathrm{ml})$. The cultures were incubated at $23^{\circ} \mathrm{C}$ under illumi- nation of 7,000 lx, and algal growth was monitored.}

\section{Effect of Bacterial Culture Filtrate on Algal Growth}

A loopful of bacterial strains was inoculated into $\mathrm{ZE}-\mathrm{CI}$ liquid media in L-shape test tubes and incubated rotatingly at $25^{\circ} \mathrm{C}$ for $2-3$ days. After two centrifugations of the bacterial cultures at $8,000 \mathrm{rpm}$ for 20 minutes, $\mathrm{pH}$ of obtained supernatants was adjusted at 7.6-7.8 and the supernatants were filtered by millipore filter $(0.22 \mu \mathrm{m})$. Then, they were transferred at $1,3,5,8$, and $10 \%(v / v)$ into axenic algal cultures in $10 \mathrm{~m} l$ ESS medium, respectively.

\section{Results}

\section{Characterization of Bacterial Strains}

The representative bacterial strains isolated from a stock culture of $C$. marina were characterized according to bacteriological tests as shown in Table 1 . The result indicated that all co-existent bacteria are gram negative, not fermentative in the Hugh \& Leifson test and positive in the catalase test. All of Flexibacter strains were negative in motili-

Table 1. Biochemical and physiological characteristics of bacterial strains

\begin{tabular}{|c|c|c|c|c|c|c|c|c|c|c|c|}
\hline Strains & Gram & Cell & Motility & Catalase & Oxidase & H \& L & Casein & Starch & DNA & Colony & Genus \\
\hline F193-1 & - & $\mathrm{fil}^{* 1}$ & - & + & \pm & - & - & - & - & $\mathrm{WP}^{*_{2}}$ & Fle. $^{* 3}$ \\
\hline F193 -2 & - & fil & - & + & \pm & - & - & - & - & WP & Fle. \\
\hline F193-3 & - & fil & - & + & \pm & - & - & - & - & WP & Fle. \\
\hline F193-4 & - & fil & - & + & \pm & - & - & - & - & WP & Fle. \\
\hline $\mathrm{Fl}-32$ & - & fil & - & + & \pm & - & - & - & - & WP & Fle. \\
\hline $\mathrm{Ab}-4$ & - & rod & + & + & + & - & + & + & + & $\mathrm{WBr}$ & Alt. \\
\hline$A b-5$ & - & rod & + & + & + & - & + & + & + & $\mathrm{WBr}$ & Alt. \\
\hline A93-1 & - & rod & + & + & + & - & - & - & + & WBr & Alt. \\
\hline Ps93-1 & - & rod & + & + & + & - & - & - & - & WGr & Pse. \\
\hline Ps93-2 & - & rod & + & + & - & - & + & \pm & - & WGr & Pse. \\
\hline F93-1 & - & L-rod & - & + & - & - & - & - & - & $Y$ & Fla. \\
\hline
\end{tabular}

*1 fil, filamentous form; L-rod, long rod.

*2 WP, whitish pink; WBr, whitish Brown; WGr, whitish grey; Y, yellow.

${ }^{*}$ Fle., Flexibacter; Alt., Alteromonas; Pse., Pseudomonas; Fla., Flavobacterium. 
ty and hydrolysis of starch, casein and DNA, whereas weak in oxidase test. On the other hand, Alteromonas strains showed to be positive in motility, oxidase test and hydrolysis of starch, casein and DNA, except a strain A931. The identification test on strains of Pseudomonas pointed out that the strains were positive in motility, oxidase and catalase test, and not fermentative in Hugh \& Leifson test.

Growth of Alga in Original Culture and Mixed-culture of Axenic Alga and Bacterial Strains

Growth curves of $C$. marina and co-existent bacteria in an non-axenic algal culture are demonstrated in Fig. 1. Algal growth reached the maximum cell number at $5.6 \mathrm{log}$ No. $/ \mathrm{m} /$ level in 15 days incubation. During 6 days incubation, total colony counts of co-existent bacterial groups including Alteromonas, Pseudomonas, and Flexibacter strains also reached maximum cell numbers at level 7.3, 7.3 , and $6.8 \log$ No. $/ \mathrm{m} l$, respectively and then followed by stationary phase in viable cell numbers. In this experiment, each bacterial group was distinguished on the basis of the colony morphology on ZE-CI agar plates; Alteromonas, Pseudomomas, and Flexibacter strains formed smooth whitish brown, smooth whitish gray and rhizoidal whitish pink colonies, respectively.

For clarifying the effect of co-existent bacteria on algal growth, a set of mixed cultures was carried out by culturing an axenic algal strain with isolated co-existent bacterial strains. After commenced by $3.9 \log \mathrm{No} . / \mathrm{m} l$ as shown in Fig. 2, the algal cell numbers in mixed cultures for all combinations with co-existent bacteria gradually increased to about $5.7 \log$ No. $/ \mathrm{m} /$ for 30 days incubation. On the other hand, the algal cell count in the axenic culture reached a maximum level at $5.2 \log \mathrm{No} / \mathrm{m} l$ in 10 days, then decreased and was not detected at all at 30 days incubation. Algal growth in mixed-cultures indicated no significant difference for all combinations with bacteria. Apart from the growth of alga in mixed-cultures, the total viable counts of bacterial groups increased to reach the cell numbers at 6.4 to $7.7 \log \mathrm{No} . / \mathrm{m} l$ as shown in Fig. 3 .

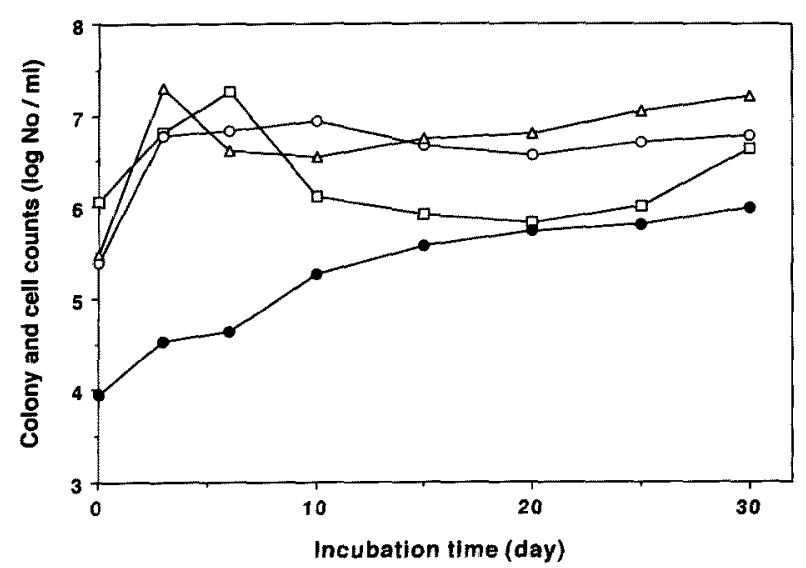

Fig. 1. Bacterial colony and algal cell counts in non-axenic culture of C. marina.

-, cell count $(\log \mathrm{No} / \mathrm{m} l)$ of $C$. marina; $O$, total colony counts $(\log \mathrm{No} / \mathrm{m} l)$ of Flexibacter strains; $\square$, total colony counts of Alteromonas strains; $\triangle$, total colony counts of Pseudomonas strains.

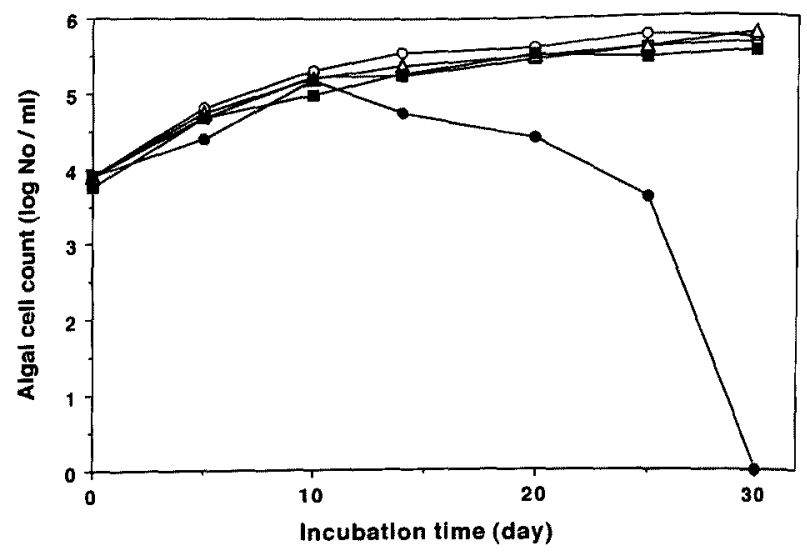

Fig. 2. Algal growth in mixed and axenic cultures.

$\square$, cell count $(\log \mathrm{No} / \mathrm{m} l)$ of C. marina in mixed culture with algal axenic strain and Flexibacter F193-3; O, in mixed culture with $\mathrm{Al}$ teromonas Ab-5; - in mixed culture with Pseudomonas Ps93-1; $\triangle$, in mixed culture with Flexibacter F193-3 and Alteromonas Ab-5; $\bullet$, cell count of $C$. marina in axenic culture.

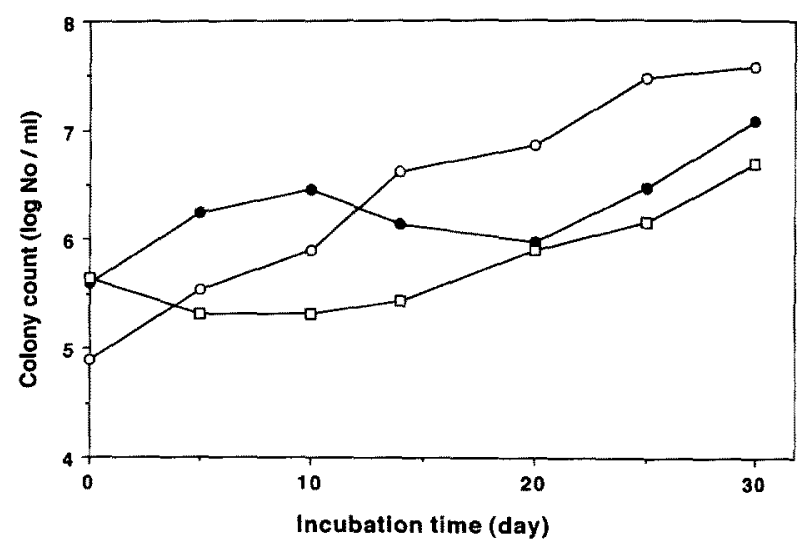

Fig. 3. Bacterial growth in algal mixed cultures.

-, colony count $(\log \mathrm{No} / \mathrm{m} l)$ of Flexibacter Fl93-3; ㅁ, Alteromonas Ab-5; O, Pseudomonas Ps93-1 in mixed culture with C. marina. The conditions of mixed cultures with $C$. marina and each bacterium are as same as in Fig. 2.

\section{Effect of Enrichment Solution and Polypepton on Algal Growth}

Figure 4 shows the effect of the supplement of enrichment solution (ESP) on algal growth. Algal cells reached the maximum level of $5.3 \log$ No. $/ \mathrm{m} l$ at 10 days, and the same level in viable cell number of the alga was maintained during 30 days incubation after the supplement of ESP solution. On the other hand, algal cells in axenic culture decreased after 10 days and was not detected at 25 days incubation without the supplement of ESP solution.

Effect of polypepton on algal growth of non-axenic culture was shown in Fig. 5. Algal cells increased gradually from the initial culture of $3.0 \mathrm{log}$. No. $/ \mathrm{m} /$ to a maximum level of $5.6 \log$. No. $/ \mathrm{m} l$ at 11 days incubation on the addition of $75 \mathrm{mg} / /$ of polypepton as well as those in ESS medium without polypepton. However, the addition of polypepton at above $100 \mathrm{mg} / \mathrm{l}$ caused a rapid decrease after 3 days and no detection in viable algal cells at 11 days incuba- 


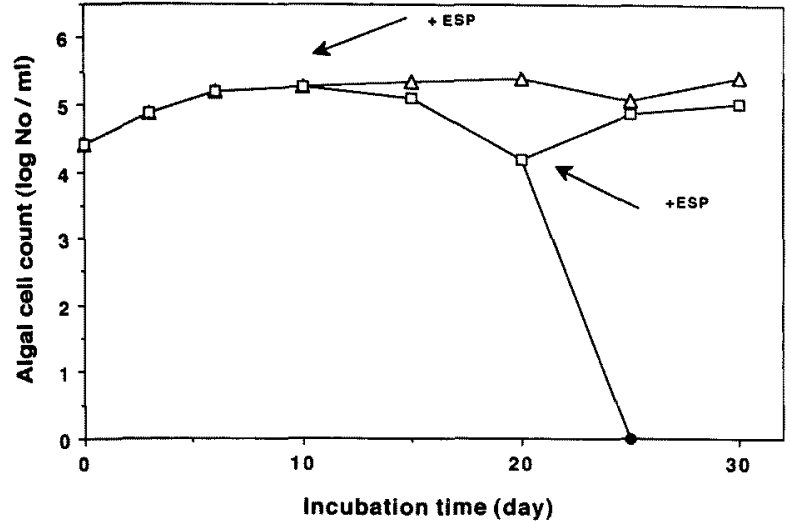

Fig. 4. Effect of the supplement of enrichment solution (ESP) on axenic algal growth.

$\triangle$, algal cell count $(\log \mathrm{No} / \mathrm{m} l)$ in ESS medium supplied with ESP at 10 days incubation; $\square$, supplied with ESP at 20 days; $\bullet$, not supplied with ESP.

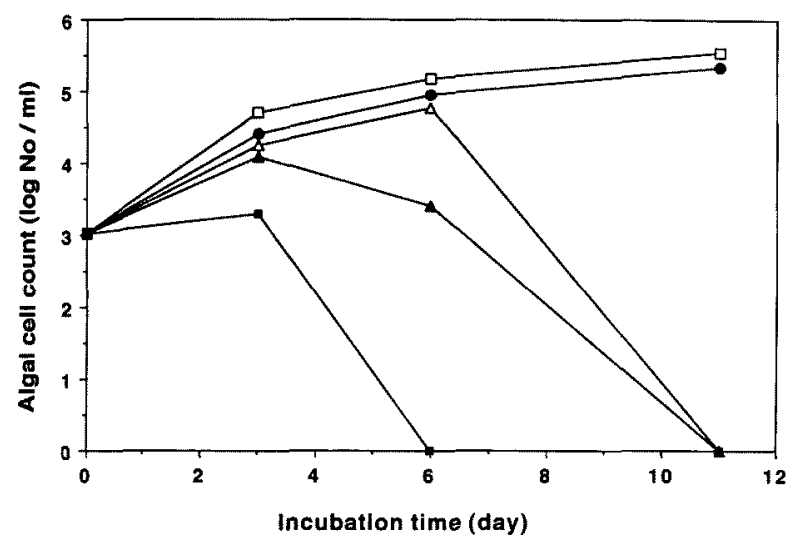

Fig. 5. Effect of various concentrations of polypepton on algal growth in non-axenic culture.

$\square$, algal cell count $(\log \mathrm{No} / \mathrm{m} l)$ in ESS medium added with polypepton at $75 \mathrm{mg} / l ; \triangle, 100 \mathrm{mg} / l ; \Delta, 150 \mathrm{mg} / l ; \backsim, 250 \mathrm{mg} / l ; \bullet$, no addition.

tion.

As shown in Fig. 6, co-existent bacteria including Flexibacter, Alteromonas and Pseudomonas spp. could grow actively and reached maximum densities during 6 days incubation on the addition of $250 \mathrm{mg} / \mathrm{l}$ of polypepton. After maximum growth at 6 days incubation, Pseudomonas and Alteromonas spp. decreased rapidly in viable counts, while Flexibacter continued to maintain viable cells at 7 $\log$ No. $/ \mathrm{m} l$ level.

\section{Effect of Bacterial Culture Filtrate on Algal Growth}

Algal cells could not grow and were killed within 7 days incubation in ESS medium added with the culture supernatant of co-existent bacterial isolates grown in a nutrient rich medium (ZE-CI medium) at $5 \%$ concentration or over, whereas at $3 \%$ concentration or less, the algal cell growth continued for $\mathbf{3 0}$ days incubation as shown in Fig. 7. The growth of axenic algal cells were maintained in the stationary phase for more than 30 days by the addition of $10 \%$ of ZE-CI medium into ESS medium. However, the al-

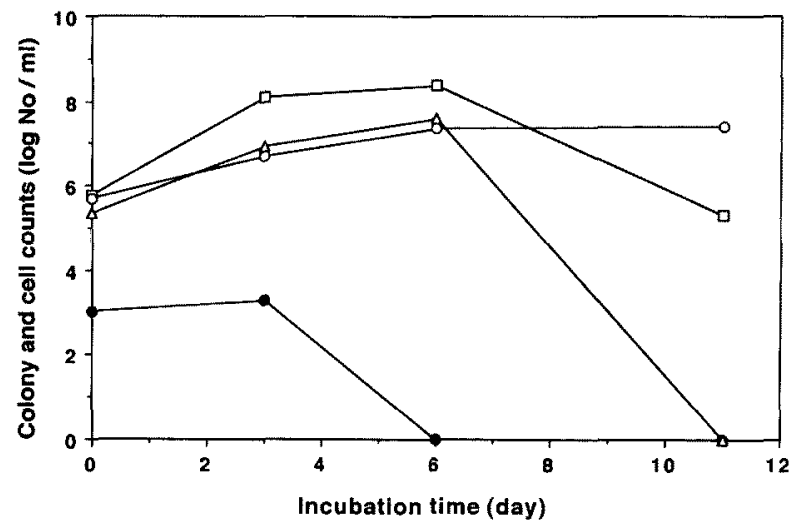

Fig. 6. Bacterial growth in non-axenic culture added with $250 \mathrm{mg} / \mathrm{l}$ polypepton.

$O$, total colony count $(\log \mathrm{No} / \mathrm{m} l)$ of Flexibacter strains; 口, $A l$ teromonas strains; $\triangle$, Pseudomonas strains; - algal cell count (log No/ml).

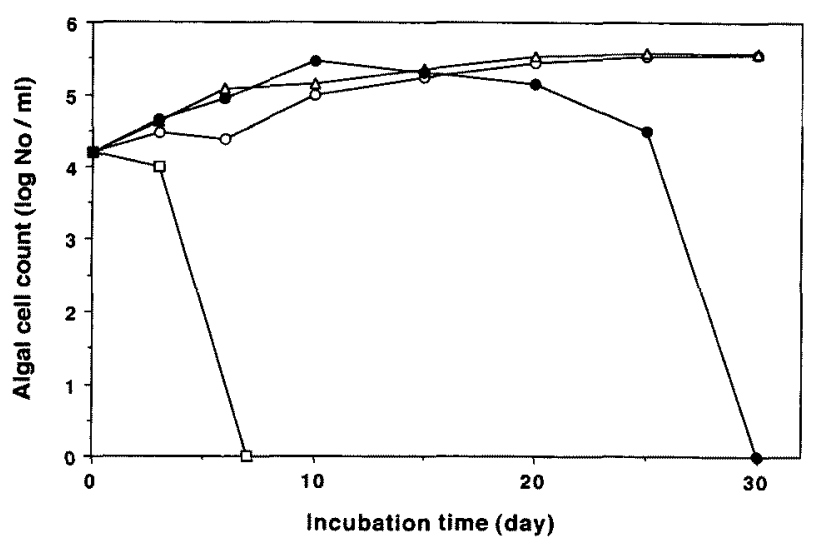

Fig. 7. Effect of the addition of culture supernatants obtained from bacterial culture in peptone medium (ZE-CI) on algal growth in axenic culture.

$\triangle$, algal cell count $(\log \mathrm{No} / \mathrm{m} l)$ in axenic culture added with $10 \%$ of ZE-CI liquid medium; $O$, algal cell count in axenic culture added with 3\% culture supernatant of Flexibacter F193-3; $\square$, added with $5 \%$ culture supernatant of Flexibacter F193-3; - algal cell count in axenic culture without the addition of bacterial culture supernatant.

gal cells in an axenic culture in ESS medium decreased gradually after the maximum density of $5.5 \log \mathrm{No} . / \mathrm{m} l$ was reached at 10 days incubation and were not detected at 30 days incubation.

\section{Discussion}

The increasing density of co-existent bacteria including Flexibacter, Alteromonas and Pseudomonas spp. in nonaxenic culture of $C$. marina immediately after transfer to fresh ESS medium, may be caused by the capability of bacteria to use some organic substances which is produced photosynthetically and excreted by the algal cells. Co-existent bacteria could adapt to algal environments and the dependence of these bacteria on algal excretion products was clearly pointed out by the increase of algal cells, followed by the increase of bacterial cells. Bell and Sakshaug ${ }^{14)}$ 
reported that a 4-fold increase in bacterial activity was enough to prevent a large accumulation of dissolved extracellular products from Skeletonema costatum. In this relationship, Ietswaart et al., ${ }^{15)}$ clarified that the algal production of dissolved organic substances and the regeneration of nutrients from dissolved organic substances by bacteria are important aspects of nutrient cycling in the sea. Glycolic acid was found to be a significant component of the total excreted carbon for natural phytoplankton. ${ }^{16)}$

The addition of enrichment solution (ESP) including vitamins, minerals and chelators to the axenic culture of C. marina after maximum growth was found to cause the regeneration of algal growth due to utilizing vitamins and minerals as growth factors. Since the presence of growth factors was ascertained to stimulate the regeneration of algal growth, it may be assumed that the nutritional requirement of algal cells is supplied by co-existent bacteria as demonstrated in non-axenic algal cultures. The major source of vitamin $B_{12}$ in open sea water has been reported to be supplied by heterotrophic bacteria and to be beneficial for algal growth. ${ }^{17)}$ Because of the supplement of growth factors by co-existent bacteria, the stationary phase of $C$. marina in non-axenic cultures was longer than that in axenic cultures.

However, the addition of polyppeton at above $100 \mathrm{mg} / \mathrm{l}$ to non-axenic cultures resulted in the fact that the algal cells decreased rapidly as the total bacterial counts increased. From these findings, it is concluded that co-existent bacteria utilized polypepton preferably than algal excretion substances and caused the death of algal cells due to some toxic low-molecular substances produced through polypepton utilization process. On the other hand, co-existent bacteria are thought to be capable of stimulating algal growth dependent on the production of growth factors or/and degradation of algal toxic metabolites by the bacteria grown on algal excretion substances in ESS medium.

\section{References}

1) J. J. Cole, G. E. Likens, and D. L. Strayer: Photosynthetically produced dissolved organic carbon: an important carbon source for planktonic bacteria. Limnol. Oceanogr., 27, 1080-1090 (1982).
2) G. E. Fogg: The ecological significance of extracellular products of phytoplankton photosynthesis. Botanica Mar., 26, 3-14 (1983).

3) T. D. Brock and J. Clyne: Significance of algal excretory products for growth of epilimnetic bacteria. Appl. Environ. Microbiol., 47, 731-734 (1984).

4) T. M. Fenchel and B. B. Jorgensen: Detritus food chains of aquatic ecosystems: The role of bacteria, in "Advances in Microbial Ecology' (ed. by M. Alexander), Plenum Press, New York, 1977, pp. 158.

5) K. H. Baker and D. S. Herson: Interactions between the diatom Thallasiosira pseudonanna and an associated pseudomonad in a mariculture system. Appl. Environ. Microbiol., 35, 791-796 (1978).

6) R. Delucca and M. O. McCracken: Observations on interaction between naturally collected bacteria and several species of algae. Hydrobiologia, 55, 71-75 (1978).

7) C. E. Riquelme, K. Fukami, and Y. Ishida: Effect of bacteria on the growth of a marine diatom, Bull. Japan. Soc. Microb. Ecol., 3, 2934 (1988).

8) K. Fukami, A. Yuzawa, T. Nishijima, and. Y. Hata: Isolation and properties of a bacterium inhibiting the growth of Gymnodinium nagasakiense. Nippon Suisan Gakkaishi., 58, 1073-1077 (1992).

9) H. W. Paerl and K. K. Gallucci: Role of chemotaxis in establishing a specific nitrogen-fixing cyanobacterial-bacterial assiociation. Science., 227, 647-649 (1985).

10) L. Provasoli, J. J. A. McLaughlin, and M. R. Droop: The development of artificial media for marine algae. Arch. Microbiol, 25, 392-428 (1957).

11) I. Imai and $M$. Yamaguchi: A simple technique for establising axenic cultures of phytoflagellates. Bull. Japan. Soc. Microb. Ecol., 9, $15-17$ (1994).

12) T, Sakata and $H$. Yasumoto: Colony formation by algicidal Saprospira sp. on marine agar plates. Fisheries Sci., 57, 2139-2143 (1991).

13) U. Simidu: Identification of marine bacteria, in "Experimental Methods for Marine Microorganisms" (ed. by H. Kadota and N. Taga), Gakkai Shuppan Center, Tokyo, 1985, pp. 228-233 (in Japanese).

14) W. H. Bell and E. Sakshaug: Bacterial utilization of algal extracellular products. 2. A kinetic study of natural populations. Limnol. Oceanogr., 25, 1021-1033 (1980).

15) T. Ietswaart, P. J. Schneider, and R. A. Prins: Utilization of organic nitrogen sources by two phytoplankton species and a bacterial isoIate in pure and mixed culture. Appl. Environ. Microbiol., 60, 1554-1560 (1994).

16) J. A. Hellebust: Excretion of some organic compounds by marime phytoplankton. Limnol. Oceanogr., 10, 192-208 (1965).

17) J. J. Cole: Interaction between bacteria and algae in aquatic ecosystems. Ann. Rev. Ecol. Syst., 13, 291-314 (1982). 